\title{
Leucosporidium Yeasts: Obligate Psychrophiles which Alter Membrane-lipid and Cytochrome Composition with Temperature
}

\author{
By K. WATSON AND HELEN ARTHUR \\ Department of Chemistry and Biochemistry, James Cook University of \\ North Queensland, Townsville 48I I, Australia \\ AND W. A. SHIPTON \\ Department of Botany, James Cook University of North Queensland
}

(Received 20 April 1976)

\begin{abstract}
SUMMARY
The temperature limits of growth of three psychrophilic yeasts, Leucosporidium frigidum, L. gelidum and L. nivalis, were examined. All species grew well at subzero temperatures $\left(-\mathrm{I}{ }^{\circ} \mathrm{C}\right)$. The maximum temperature of growth was significantly higher with glucose as substrate $\left(18\right.$ to $20^{\circ} \mathrm{C}$ ) than with ethanol ( 17 to $\left.18{ }^{\circ} \mathrm{C}\right)$. There was a positive correlation between the growth temperature and the degree of fattyacid unsaturation of the cell lipids; the lower the temperature, the greater the degree of fatty-acid unsaturation. At subzero temperatures $\left(-\mathrm{r}{ }^{\circ} \mathrm{C}\right)$ with ethanol as substrate, $90 \%$ of the total fatty acid was unsaturated with linolenic ( 35 to $50 \%$ ) and linoleic ( 25 to $30 \%$ ) acids predominating. At temperatures close to the maximum for growth, linolenic acid accounted for less than $20 \%$ of the total fatty acid and oleic ( 20 to $40 \%$ ) and linoleic ( 30 to $50 \%$ ) acids were the major components. Difference spectra of intact cells showed marked changes in the ratios and amounts of individual cytochromes as a function of growth temperature. In L. frigidum with glucose as substrate, the ratios of cytochromes $a+a_{3}: b: c$ at 8 and $\mathrm{I} 9{ }^{\circ} \mathrm{C}$ were $\mathrm{I}: \mathrm{I} \cdot \mathrm{I}: 2 \cdot 9$ and $\mathrm{I}: 2 \cdot 3: \mathrm{I} 6 \cdot 7$ respectively. Similar changes in cytochrome ratios were noted for $L$. gelidum, but changes were much less marked for $L$. nivalis. The temperature effects were interpreted as supporting the view that membrane structure and composition are fundamental to temperature adaptation in psychrophilic yeasts.
\end{abstract}

\section{INTRODUCTION}

The lipid compositions of a number of biological systems show an increase in unsaturation with a decrease in environmental temperature. There have been numerous reports on microorganisms which conform to this phenomenon (Gaughran, 1947; Marr \& Ingraham, 1962; Kates, I964; Cullen, Philips \& Shipley, I97 I); but despite intensive studies no unifying theory on the relationship between lipid unsaturation and temperature has been firmly established.

The initial studies on yeast cells by Kates \& Baxter (1962), in which the fatty-acid composition of Candida lipolytica was compared with those of Candida species capable of growth at low temperatures, showed a trend to greater lipid unsaturation at lower growth temperatures. Essentially similar results on Candida yeasts were reported by Rose and co-workers (McMurrough \& Rose, I97 I, I973); but little difference in the fatty-acid composition or in the degree of unsaturation was observed in Saccharomyces cerevisiae grown at $\mathrm{I} 5$ and $30^{\circ} \mathrm{C}$ (Hunter \& Rose, I972).

The availability of well characterized yeasts capable of growing at subzero temperatures (di Menna, I966; Larkin \& Stokes, I968; Fell et al., 1969) offered an opportunity to gain 
new insight into the relationship, if any, between the degree of lipid unsaturation and growth temperature. Furthermore, it is well established that lipid unsaturation plays an important role in determining the structure and function of yeast mitochondria (Paltauf \& Schatz, 1969; Plattner \& Schatz, 1969; Watson et al., I971, I975 b; Watson, Bertoli \& Griffiths, I975a).

In this report we describe studies on the effect of growth temperature on the fatty-acid and cytochrome compositions of three psychrophilic yeasts belonging to the genus Leucosporidium.

\section{METHODS}

Yeast cultures. The yeast strains used were received from di Menna (I966). Leucosporidium frigidum strain 5AI (CBS5270) was formerly known as Candida frigida but it has been reclassified on the basis of its heterobasidiomycetous life-cycle (Fell et al., 1969). Leucosporidium gelidum strain $2 \mathrm{AHIO}$ and $L$. nivalis strain $3 \mathrm{AHI} 7$ were also formerly described as Candida species and have been reclassified (Fell et al., 1969).

Stock cultures were maintained on agar slopes containing (g/l distilled water): glucose, 20; yeast extract, I0; peptone, 5; agar, I5; $\mathrm{pH} \mathrm{6.I.}$

Growth conditions. The effect of temperature on yeast growth was studied in media containing I \% yeast extract, $0.5 \%$ peptone and mineral salts (Wickerham, 1946), with either $0.5 \%(\mathrm{w} / \mathrm{v})$ ethanol or $2 \%(\mathrm{w} / \mathrm{v})$ glucose as the carbon source. Cells were grown in $100 \mathrm{ml}$ medium in $250 \mathrm{ml}$ conical flasks shaken at $\mathrm{I} 80 \mathrm{rev} \mathrm{min}^{-1}$ in Paton orbital shakers (Paton Industries, St Peters, South Australia) at controlled temperatures. An inoculum ( $4 \%$ w/v) from a starter culture grown to late-exponential phase was used in all experiments. Cells for lipid and cytochrome assays were harvested at the end of the exponential-growth phase. The dry weight of cells $\left[\mathrm{mg}(\mathrm{ml} \text { medium })^{-1}\right]$ corresponding to this stage of growth was determined from growth curves at the appropriate temperature with either ethanol or glucose as substrate.

Dry weight determination. The dry weight of cells was determined by transferring samples of yeast suspension to mm-graduated tubes and centrifuging at $3000 \mathrm{~g}$ for $\mathrm{I} 0 \mathrm{~min}$. The graduated tubes were calibrated by comparison of dry weights determined by direct weighing of cells after drying at $\mathrm{I} I \mathrm{O}^{\circ} \mathrm{C}$ for $24 \mathrm{~h}$.

Fatty-acid analysis. Cells were harvested at the appropriate growth phase and washed twice with distilled water. Portions (I to $2 \mathrm{~g}$ wet wt) were refluxed for $4 \mathrm{~h}$ in $20 \%(\mathrm{w} / \mathrm{v}$ ) $\mathrm{KOH}$, cooled and extracted three times with petroleum ether (b.p. 40 to $60{ }^{\circ} \mathrm{C}$ ). The ether layers, containing the non-polar lipids, were discarded and the aqueous layer was acidified with concentrated $\mathrm{HCl}$ to $\mathrm{pH}$ I to 2 . Polar lipids were extracted with petroleum ether (b.p. 40 to $60^{\circ} \mathrm{C}$ ) and the combined ether extracts were dried over anhydrous sodium sulphate and then evaporated to dryness under reduced pressure in a rotary evaporator. The methyl esters of the fatty acids were prepared by acid-catalysed esterification using methanolic $0.5 \mathrm{M}-\mathrm{HCl}$. They were heated at $60^{\circ} \mathrm{C}$ for $\mathrm{I} \mathrm{h}$, and then extracted into $\mathrm{n}$-hexane; extracts were dried over sodium sulphate and reduced to a small volume under reduced pressure. Samples were analysed by gas-liquid chromatography using a Shimadzu GC-4APF gas chromatograph (Shimadzu, Seisakusho, Kyoto, Japan) fitted with a dual flame ionization detector. Assays were carried out using a Silar IoC (Applied Science Laboratories, Inglewood, California, U.S.A.) column $2 \mathrm{~m}$ in length operating at $175^{\circ} \mathrm{C}$, with the injection and detection ports set at $225^{\circ} \mathrm{C}$, and the carrier gas (nitrogen) flow rate at $40 \mathrm{ml} \mathrm{min}^{-1}$. Individual fatty acids were identified by comparing their retention times with those of standard methyl esters (Applied Science Laboratories). 
Table I. Specific growth rates of Leucosporidium yeasts at different temperatures

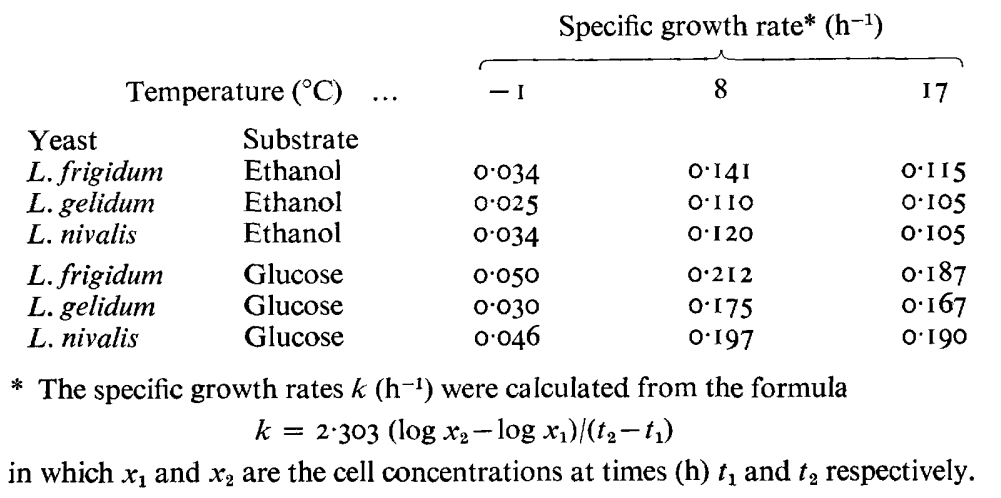

The percentage by weight of each fatty acid was estimated by triangulation.

Cytochrome determination. Cytochrome composition of intact cells was determined by difference spectroscopy using a $10 \mathrm{~mm}$ light-path (final volume $2.5 \mathrm{ml}$ ) in a Pye Unicam SP80o spectrophotometer. Cells were washed in distilled water, once in $50 \mathrm{~mm}$-phosphate buffer $\mathrm{pH} 7.0$, and suspended in $50 \mathrm{mM}$-phosphate buffer $\mathrm{pH} 7.0$ to a concentration of 25 to $35 \mathrm{mg}$ dry wt $\mathrm{ml}^{-1}$. The contents of the sample cuvette were reduced by adding a few grains of sodium dithionite and the contents of the reference cuvette were oxidized by adding Io $\mu 1 \mathrm{H}_{2} \mathrm{O}_{2}(30 \%$, w/v). The following wavelength pairs and extinction coefficients were used in quantitative measurements: cytochrome $c, 550$ and $540 \mathrm{~nm}, \epsilon=\mathrm{I} 9 \times 10^{3} 1 \mathrm{~mol}^{-1}$ $\mathrm{cm}^{-1}$ (Wilson \& Epel, I968); cytochrome $b, 560$ and $540 \mathrm{~nm}, \epsilon=22 \times 10^{3} 1 \mathrm{~mol}^{-1} \mathrm{~cm}^{-1}$ (Wilson \& Epel, I968); and cytochrome $a+a_{3}, 605$ and $630 \mathrm{~nm}, \epsilon=24 \times \mathrm{IO}^{3} 1 \mathrm{~mol}^{-1} \mathrm{~cm}^{-1}$ (van Gelder, I966).

\section{RESULTS}

\section{Growth temperatures}

The specific growth rates, as measured during the exponential-growth phase, of the Leucosporidium yeasts were similar at growth temperatures of 8 and $17{ }^{\circ} \mathrm{C}$ (Table I), but for a given temperature the specific growth rates on glucose as substrate were higher than on ethanol. All three yeasts grew well at subzero temperatures $\left(-\mathrm{I}^{\circ} \mathrm{C}\right)$ with average specific growth rates of 0.042 and $0.03 \mathrm{I}$ with glucose and ethanol as substrates respectively. The final cell yield (expressed as $\mathrm{mg}$ dry wt cells $\mathrm{ml}^{-1}$ ) was highest for cells grown at $-\mathrm{I}{ }^{\circ} \mathrm{C}$ (Figs. I and 2).

The maximum growth temperature for $L$. frigidum was 19 to $20^{\circ} \mathrm{C}$ on glucose and significantly lower, 17 to $18^{\circ} \mathrm{C}$, on ethanol (Figs. 2 and 3). Leucosporidium gelidum and L. nivalis were more sensitive to high temperatures and were unable to grow on ethanol or glucose at much above 17 to $18{ }^{\circ} \mathrm{C}$ (Fig. 3).

\section{Fatty-acid composition}

The fatty-acid composition of the polar lipid fraction of the Leucosporidium yeasts showed a predominance of $\mathrm{C}_{18}$ unsaturated fatty acids at all growth temperatures. The major fatty acids were oleic $\left(\mathrm{C}_{18: 1}\right)$, linoleic $\left(\mathrm{C}_{18: 2}\right)$ and $\alpha$-linolenic $\left(\alpha-\mathrm{C}_{18: 3}\right)$ acids with traces of $\gamma$-linolenic $\left(\gamma-\mathrm{C}_{18: 3}\right)$ acid in cells grown at $-\mathrm{I}{ }^{\circ} \mathrm{C}$. The main saturated fatty acid was palmitic $\left(\mathrm{C}_{16: 0}\right)$ acid. In $L$. frigidum and $L$. nivalis, a fatty-acid unsaturation index of greater than 2 


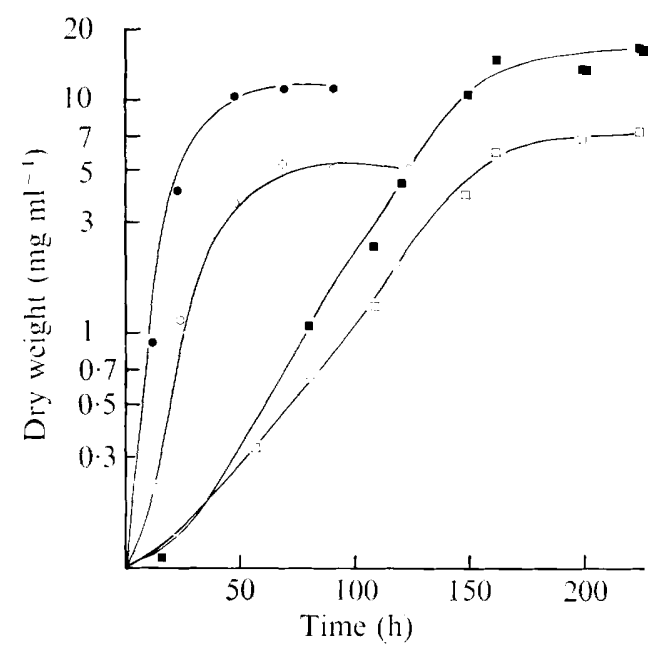

Fig. I. Growth curves of $L$. frigidum on glucose $(\square, \bullet)$ and ethanol $(\square, O)$ at $-1{ }^{\circ} \mathrm{C} .(\square, \square)$ and $8{ }^{\circ} \mathrm{C}(\bullet, O)$.

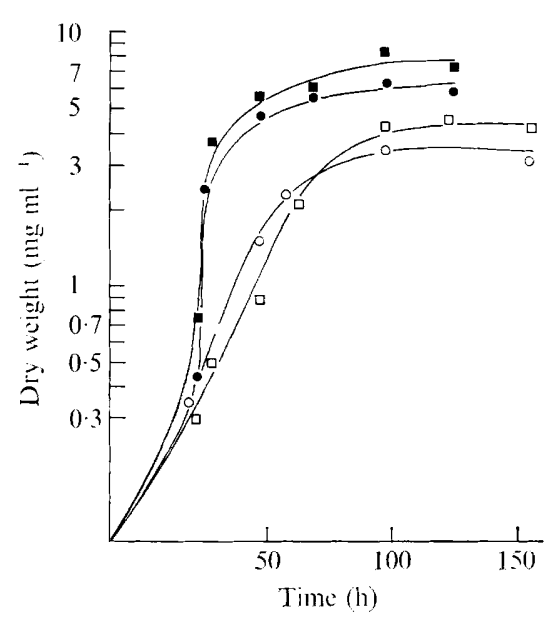

Fig. 2

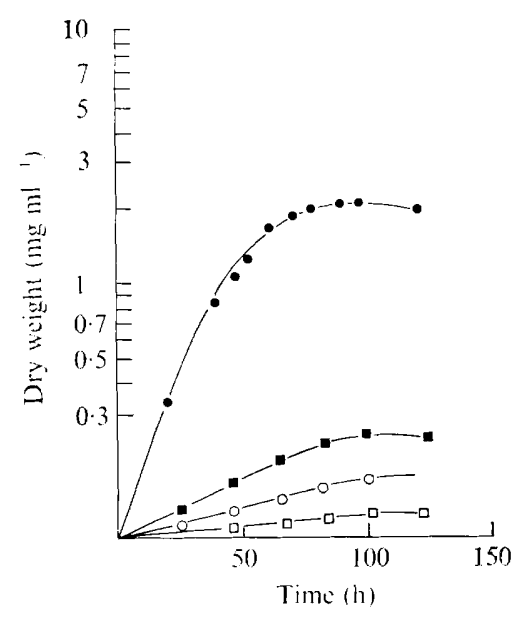

Fig. 3

Fig. 2. Growth curves of L. frigidum $(\odot, \bigcirc)$ and L. nivalis $(\square, \square)$ on glucose $(\odot, \square)$ and ethanol $(\mathrm{O}, \square)$ at $17^{\circ} \mathrm{C}$.

Fig. 3. Growth curves of L. frigidum $(\boldsymbol{\Theta}, \bigcirc)$ and L. nivalis $(\boldsymbol{\square}, \square)$ on glucose $(\boldsymbol{O}, \mathbf{\square})$ and ethanol $(\mathrm{O}, \square)$ at $19{ }^{\circ} \mathrm{C}$.

was calculated for cells grown at - I and $8{ }^{\circ} \mathrm{C}$ (Table 2). A lower unsaturation index was noted for $L$. gelidum cells, with the highest index $(\mathrm{I} \cdot 78)$ for cells grown at $-\mathrm{I}{ }^{\circ} \mathrm{C}$. In general, cells grown on ethanol contained more unsaturated fatty acids than the corresponding cells grown on glucose (compare data for cells grown at $8{ }^{\circ} \mathrm{C}$, Table 2).

A comparison of the data for cells grown on ethanol showed that as the growth temperature was lowered there was a progressive increase in the proportion of linoleic $\left(\mathrm{C}_{18: 2}\right)$ and linolenic $\left(\mathrm{C}_{18: 3}\right)$ acids with a corresponding decrease in the proportion of oleic $\left(\mathrm{C}_{18: 1}\right)$ acid. Furthermore, there was a positive correlation between the growth temperature and the degree of 


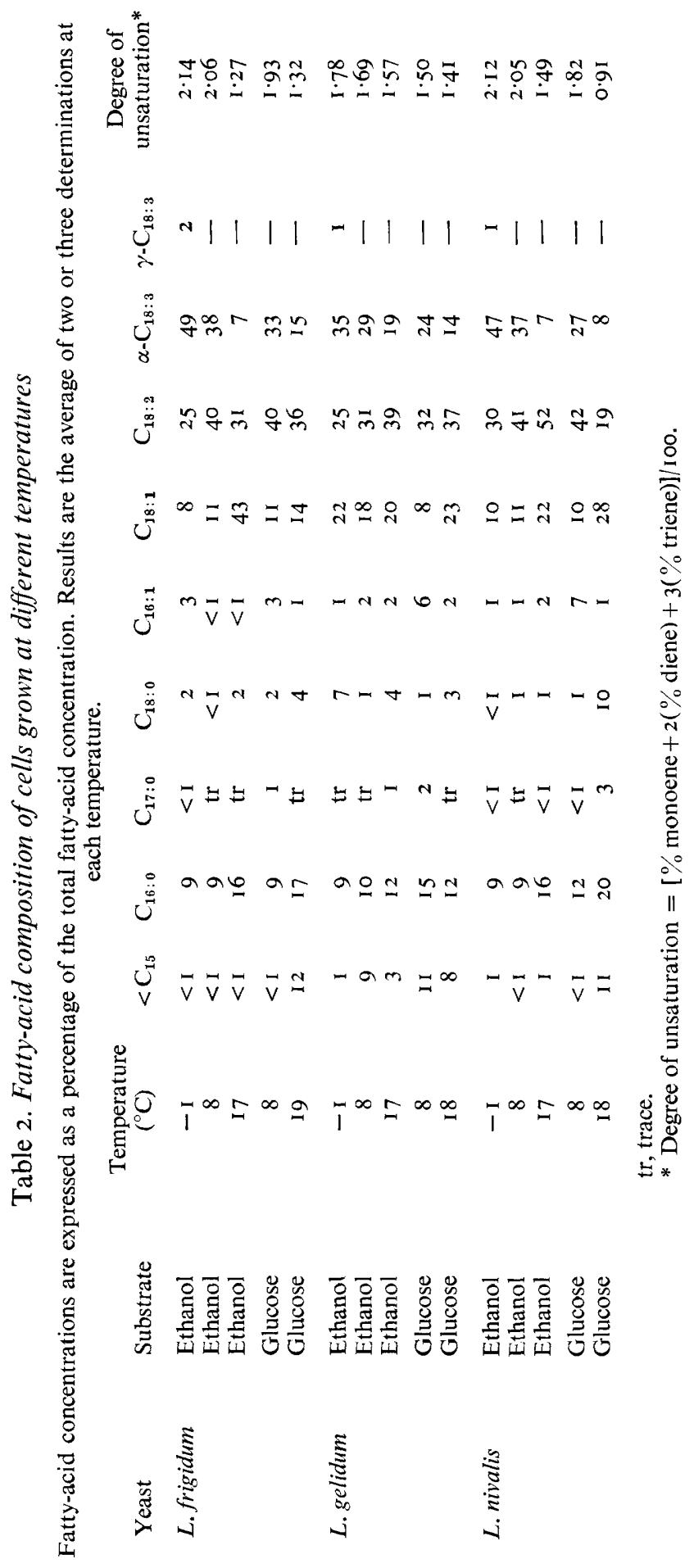


Table 3. Cytochrome composition of cells grown at different temperatures

Results are the average of two or three determinations at each temperature.

\begin{tabular}{|c|c|c|c|c|c|c|}
\hline \multirow[b]{2}{*}{ Yeast } & \multirow[b]{2}{*}{ Substrate } & \multirow{2}{*}{$\begin{array}{l}\text { Temperature } \\
\left({ }^{\circ} \mathrm{C}\right)\end{array}$} & \multicolumn{3}{|c|}{$\begin{array}{l}\text { Cytochrome concn } \\
\left.[\text { nmol (mg protein })^{-1}\right]\end{array}$} & \multirow{2}{*}{$\begin{array}{c}\text { Cytochrome ratio } \\
\qquad a+a_{3}: b: c\end{array}$} \\
\hline & & & $a+a_{3}$ & $b$ & $c$ & \\
\hline \multirow[t]{5}{*}{ L. frigidum } & Ethanol & $-\mathbf{I}$ & 38 & 29 & $9 \mathrm{I}$ & $I: 0 \cdot 8: 2 \cdot 4$ \\
\hline & Ethanol & 8 & 40 & 26 & 100 & $I: 0.7: 2 \cdot 5$ \\
\hline & Ethanol & 17 & 47 & 43 & 137 & $I: 0 \cdot 9: 2 \cdot 4$ \\
\hline & Glucose & 8 & $3 \mathrm{I}$ & 33 & $9 \mathrm{I}$ & $\mathrm{J}: \mathrm{I} \cdot \mathrm{I}: 2.9$ \\
\hline & Glucose & 19 & 9 & $2 \mathrm{I}$ & 150 & $1: 2 \cdot 3: 16 \cdot 7$ \\
\hline \multirow[t]{5}{*}{ L. gelidum } & Ethanol & $-I$ & 42 & 36 & $8 \mathrm{I}$ & $I: 0 \cdot 9: I \cdot 9$ \\
\hline & Ethanol & 8 & 46 & 33 & 77 & $1: 0 \cdot 7: 1 \cdot 7$ \\
\hline & Ethanol & 17 & 30 & 44 & 149 & $I: I \cdot 5: 5 \cdot 0$ \\
\hline & Glucose & 8 & 28 & 45 & 76 & $I: 1 \cdot 6: 2 \cdot 7$ \\
\hline & Glucose & 18 & 6 & I4 & 84 & $I: 2 \cdot 3: 14 \cdot 0$ \\
\hline \multirow[t]{5}{*}{ L. nivalis } & Ethanol & $-I$ & 44 & 40 & 76 & $\mathrm{I}: 0 \cdot 9: \mathrm{I} \cdot 8$ \\
\hline & Ethanol & 8 & 42 & 38 & 84 & I : $0 \cdot 9: 2 \cdot 0$ \\
\hline & Ethanol & 17 & $3 I$ & 54 & 134 & $I: I \cdot 7: 4 \cdot 3$ \\
\hline & Glucose & 8 & 27 & 40 & 42 & $I: I \cdot 5: I \cdot 6$ \\
\hline & Glucose & I 8 & 19 & 24 & 74 & $1: 1 \cdot 3: 3 \cdot 9$ \\
\hline
\end{tabular}

fatty-acid unsaturation; the lower the temperature, the greater the degree of fatty-acid unsaturation.

\section{Cytochrome composition}

For a given temperature and carbon source, either ethanol or glucose, the cytochrome compositions of the three Leucosporidium yeasts were remarkably similar (Table 3 ). With ethanol as substrate, no significant differences in cytochrome composition were noted between cells grown at $-\mathrm{I}$ and $8{ }^{\circ} \mathrm{C}$. However, at temperatures close to the maximum for growth on ethanol, L. gelidum and L. nivalis showed a twofold increase in the ratio of cytochrome $c$ to cytochromes $a+a_{3}$. The change in cytochrome ratio as a function of growth temperature was most marked in cells grown on glucose. At temperatures close to the maximum for growth ( 18 to $20^{\circ} \mathrm{C}$ ), there was a dramatic decrease in the concentration of cytochromes $a+a_{3}$ compared with that in cells grown at $8{ }^{\circ} \mathrm{C}$, and a concurrent increase in cytochrome $c$ concentration. These two factors accounted for the two- to fivefold increase in the ratio of cytochrome $c$ to cytochromes $a+a_{3}$ at temperatures close to the maximum for growth. The increase in the proportion of cytochrome $c$ was such that cells grown at I 8 to $20^{\circ} \mathrm{C}$ on glucose as carbon source were visibly pink.

Changes in cytochrome $b$ with temperature were somewhat variable. With ethanol as substrate there was a trend towards an increase in concentration with increasing temperature; with glucose, the reverse pattern was observed.

\section{DISCUSSION}

The data on the temperature limits of growth of L. frigidum, L. gelidum and L. nivalis clearly establish these yeasts as obligate psychrophiles unable to grow at temperatures above 18 to $20^{\circ} \mathrm{C}$. These results are essentially in agreement with the original observations of di Menna (1966) and Sinclair \& Stokes (I965). On the basis of the definition that a psychrophilic yeast is one that is unable to grow at temperatures above $20{ }^{\circ} \mathrm{C}$, the above species, 
together with Torulopsis psychrophila (Goto, Sugiyama \& Iizuka, 1969) and certain other species of Leucosporidium (Fell et al., 1969), constitute the only obligate psychrophilic yeasts so far isolated.

Kates \& Baxter (1962) first reported a higher degree of fatty-acid unsaturation in C. lipolytica cells grown at $10^{\circ} \mathrm{C}$ than in cells grown at $25^{\circ} \mathrm{C}$ and they made a direct comparison with $L$. scottii (formerly Candida scottii), a psychrophile, grown at $10{ }^{\circ} \mathrm{C}$. However, this comparison is not strictly valid since differences in fatty-acid composition may simply reflect differences between the yeast species rather than being directly attributable to temperature effects. Nevertheless, a high degree of fatty-acid unsaturation (unsaturation index $1 \cdot 72$ ) was noted in $L$. scottii cells grown at $10{ }^{\circ} \mathrm{C}$. Similar studies on Candida yeasts were made by McMurrough \& Rose (I97I, I973) who, while noting a relationship between fatty-acid unsaturation of cells and growth temperature, reported that these changes were also partially dependent on the age of the cells.

In our studies we have avoided complications arising from differences in species and have taken care in comparative fatty-acid analysis to harvest cells at the same stage of growth. Our results on Leucosporidium yeasts clearly establish a relationship between growth temperature and the fatty-acid unsaturation index. The indexes $(\mathrm{I} \cdot 8$ to $2 \cdot \mathrm{I})$ for cells grown at $-\mathrm{I}$ and $8^{\circ} \mathrm{C}$ are the highest reported for yeast cells and amongst the highest for fungi in general (see Weete, 1974). A high unsaturation index, necessary to maintain the cellular membranes in a fluid or semi-fluid state at low temperatures, may be a prerequisite for obligate psychrophilic yeasts. In this respect the absence of obligate psychrophilic yeasts belonging to the genus Saccharomyces may be related to their limited ability to synthesize linoleic and linolenic acids. Conversely, it may be predicted that some yeasts belonging to genera such as Torulopsis and Candida which are capable of synthesizing polyunsaturated fatty acids are likely to be obligate psychrophiles. The isolation from Antarctica of T.psychrophila (Goto et al., I969), a yeast unable to grow at temperatures above $20{ }^{\circ} \mathrm{C}$, is one such obligate psychrophile.

In previous work utilizing an unsaturated-fatty-acid auxotroph of $S$. cerevisiae, we reported that the degree of fatty-acid unsaturation was an important parameter in determining the concentration and ratios of cytochromes in intact cells and isolated mitochondria (Watson et al., I975a). The lower the membrane-lipid unsaturation, the lower was the concentration of cytochromes. Cytochromes $a+a_{3}$ were particularly sensitive to changes in the degree of membrane-lipid unsaturation. A similar phenomenon, in relation to growth temperature, appears to be operative in the present studies on obligate psychrophilic yeasts. At the maximum temperature for growth on glucose, the final cell yield is less than that at the lower temperatures indicating that glucose repression of cytochrome synthesis may occur.

The high concentration of cytochrome $c$ in cells grown at temperatures close to the maximum for growth may be seen as an attempt by the cells to compensate for the decrease in cytochromes $a+a_{3}$, by involving alternative pathways of electron transport. This situation may be analogous to that of 'poky' mutants of Neurospora crassa which are characterized by abnormally high concentrations of cytochrome $c$ and low concentrations of cytochromes $a+a_{3}$ (Haskins et al., 1954; Tissieres, Mitchell \& Haskins, 1953). Alternative pathways of electron transport and oxidative phosphorylation have been shown to occur in these mutants (von Jagow, Weiss \& Klingenberg, I 973; Drabikowska, Kosmakos \& Brodie, 1974).

In summary, our evidence indicates that the function and composition of the cellular membranes are important factors in temperature adaptation in psychrophilic yeasts, manipulation of the fatty-acid unsaturation index allowing cells to alter their membrane fluidity, and hence function, with changes in temperature. 
This work was supported by a grant to K.W. and W.A.S. from the Australian Research Grants Committee. H.A. acknowledges receipt of an Australian Government Postgraduate Scholarship.

\section{REFERENCES}

Cullen, J., Philips, M. C. \& Shipley, G. G. (1971). Effects of temperature on composition and physical properties of lipids of Pseudomonas fluorescens. Biochemical Journal 125, 733-742.

Drabikowska, A., Kosmakos, F. C. \& Brodie, A. F. (I974). Studies of respiratory components and oxidative phosphorylation in mitochondria of mi-I Neurospora crassa. Journal of Bacteriology 117, 733-740.

Fell, J. W., Statzell, A. C., Hunter, I. L. \& Phaff, H. J. (1969). Leucosporidium gen.n. the heterobasidiomycetous stage of several yeasts of the genus Candida. Antonie van Leeuwenhoek 35, 433-462.

Gaughran, E. R. L. (1947). The thermophilic microorganisms. Bacteriological Reviews II, I 89-225.

GELDER, B. F. VAN (1966). The extinction coefficient of cytochromes $a$ and $a_{3}$. Biochimica et biophysica acta II8, 36-46.

Goto, S., SugiYama, J. \& IIzUKa, H. (1969). A taxonomic study of Antarctic yeasts. Mycologia 69, 748-774.

Haskins, F. A., Tissieres, A. A., Mitchell, H. K. \& Mitchell, M. B. (I954). Cytochromes and the succinic oxidase system of Poky strains of Neurospora. Journal of Biological Chemistry 200, 819-826.

HunTER, K. \& ROSE, A. H. (1972). Lipid composition of Saccharomyces cerevisiae as influenced by growth temperature. Biochimica et biophysica acta 260, 639-653.

JAGow, G. von, Weiss, H. \& KLINGENBERG, M. (1973). Comparison of the respiratory chain of Neurospora wild-type and the mi-mutants mi-1 and mi-3. European Journal of Biochemistry 33, 140-157.

KATES, M. (1964). Bacterial lipids. Advances in Lipid Research 2, 17-90.

KATES, M. \& BAXTER, R. M. (1962). Lipid composition of mesophilic and psychrophilic yeasts (Candida species) as influenced by environmental temperature. Canadian Journal of Biochemistry and Physiology $40,1213-1227$.

LARKIN, J. M. \& Stokes, J. L. (1968). Growth of psychrophilic microorganisms at subzero temperatures. Canadian Journal of Microbiology 14, 97-107.

MCMUrRough, I. \& Rose, A. H. (I97I). Effects of temperature variation on the fatty acid composition of Candida utilis. Journal of Bacteriology 107, 753-758.

McMurrough, I. \& Rose, A. H. (I973). Effects of temperature variation on fatty acid composition of a psychrophilic Candida species. Journal of Bacteriology II4, 45I-452.

MARR, A. G. \& INGRAHAM, J. L. (1962). Effect of temperature on the composition of fatty acids in Escherichia coli. Journal of Bacteriology 84, I $260-1267$.

Menna, M. E. DI (1966). Three new psychrophilic yeasts from Antarctica soil: Candida nivalis, Candida gelida and Candida frigida spp. n. Antonie van Leeuwenhoek 32, 25-28.

Paltauf, F. \& Schatz, G. (1969). Promitochondria of anaerobically grown yeast. II. Lipid composition. Biochemistry, New York 8, 335-339.

Plattner, H. \& Schatz, G. (1969). Promitochondria of anaerobically grown yeast. III. Morphology. Biochemistry, New York 8, 339-343.

SinCLAIR, N. A. \& StOKES, J. L. (1965). Obligately psychrophilic yeasts from the polar regions. Canadian Journal of Microbiology Ir, 259-269.

Tissieres, A. A., Mitchell, H. K. \& HAskins, F. A. (I953). Studies on the respiratory system of the Poky strain of Neurospora. Journal of Biological Chemistry 205, 423-433.

Watson, K., Bertoli, E. \& Griffiths, D. E. (1975a). Phase transitions in yeast mitochondria. The effect of temperature on the energies of activation of the respiratory enzymes of Saccharomyces cerevisiae. Biochemical Journal 146, 40I-407.

Watson, K., Haslam, J. M., Veitch, B. \& Linnane, A. W. (197I). Mitochondrial precursors in anaerobically grown yeasts. In Autonomy and Biogenesis of Mitochondria and Chloroplasts, pp. 162-174. Edited by N. K. Boardman, A. W. Linnane and R. M. Smillie. Amsterdam: North-Holland.

Watson, K., Houghton, R. L., Bertoli, E. \& Griffiths, D. E. (1975b). Membrane-lipid unsaturation and mitochondrial function in Saccharomyces cerevisiae. Biochemical Journal 146, 409-4I6.

WeETE, J. D. (1974). (Editor.) Fungal Lipid Biochemistry. New York and London: Plenum Press.

WILSON, D. \& EPEL, D. (I968). The cytochrome system of sea urchin sperm. Archives of Biochemistry and Biophysics 126, 83-90.

WICKERHAM, L. J. (1946). A critical evaluation of the nitrogen assimilation tests commonly used in the classification of yeasts. Journal of Bacteriology 52, 293-30r. 